\title{
Pertumbuhan planlet anggrek Cymbidium bicolor Lindl. pada tahap subkultur dengan variasi media
}

\author{
Growth of Cymbidium bicolor Lindl. plantlet during subculture with variation of media
}

Fakhri Fadhlurrohman Pratama*, Nintya Setiari, Yulita Nurchayati

Departemen Biologi, Fakultas Sains dan Matematika, Universitas Diponegoro

Jl. Prof. H. Soedarto, SH., Tembalang Semarang, Jawa Tengah, Indonesia 50275

*Email: fakhrifadhlur9@gmail.com

Diterima 18 Desember 2020 Disetujui 10 Mei 2021

\section{INTISARI}

Cymbidium bicolor merupakan salah satu anggrek di Indonesia yang memiliki bunga yang indah dan tahan lama, sehingga berpotensi menjadi tanaman hias. Bunga anggrek $C$. bicolor mulai banyak dieksploitasi dari alam karena memiliki nilai ekonomis tinggi. Oleh karena itu, diperlukan metode untuk perbanyakan yaitu kultur jaringan tumbuhan. Salah satu tahap pada kultur jaringan tumbuhan adalah subkultur. Jenis media yang digunakan pada tahap subkultur mempengaruhi pertumbuhan planlet. Media yang digunakan antara lain Murashige and Skoog (MS), Vacin and Went (VW), dan New Phalaenopsis (NP). Penelitian ini bertujuan untuk menganalisis jenis media berbeda pada tahap subkultur. Metode yang digunakan adalah kultur jaringan tumbuhan pada tahap subkultur planlet ke media perlakuan (MS, VW, dan NP). Planlet C. bicolor disubkultur dalam media MS, VW, NP dan diamati selama 2 bulan. Parameter yang diamati adalah kemunculan daun, jumlah daun, panjang daun, lebar daun, jumlah akar, panjang akar, dan jumlah tunas. Penelitian ini menggunakan Rancangan Acak Lengkap faktor tunggal yaitu Jenis Media dengan 15 ulangan. Data dianalisis dengan ANOVA pada signifikansi 95\%. Hasil penelitian menunjukkan perlakuan jenis media berpengaruh nyata terhadap semua parameter. Media MS merupakan media terbaik untuk kemunculan daun (11 hari), jumlah daun (4.92), panjang daun $(1,56 \mathrm{~cm})$, lebar daun $(0,33 \mathrm{~cm})$, jumlah akar $(2,67)$, panjang akar $(2,73 \mathrm{~cm})$, dan jumlah tunas $(4,00)$. Media MS merupakan media terbaik untuk pertumbuhan $C$. bicolor pada tahap subkultur.

Kata kunci: Cymbidium bicolor, subkultur, pertumbuhan, jenis media

\begin{abstract}
Cymbidium bicolor is one of the orchids in Indonesia which has beautiful and longlasting flowers, so it has potential to become an ornamental plant and has economic value. The method of propagation generally is tissue culture. One of the stages in plant tissue culture is subculture. The variation of media used at the subculture stage make an effect for growth of plantlet. Media usually can be used include Murashige and Skoog (MS), Vacin and Went (VW), and New Phalaenopsis (NP). This study aims is to analyze the variation of media during the subculture. The method used was tissue culture in subculture with media as treatment. Cymbidium bicolor planlets were subcultured into MS, VW, and NP and observed for 2 months. The parameters observed were the leaf emergence, the number of leafs, leaf length, leaf width, the number of roots, root length, and the number of shoots. This study used a completely randomized design with single factor and 15 replicates. Data were analyzed by ANOVA with $95 \%$ significance. Treatment of variation of media significantly affected all parameters. Murashige and Skoog (MS) medium was the best medium for
\end{abstract}


leaf emergence (11 days), the number of leafs $(4,92)$, leaf length $(1,56 \mathrm{~cm})$, leaf width $(0,33 \mathrm{~cm})$, the number of roots $(2,67)$, root length $(2,73 \mathrm{~cm})$, and the number of shoots $(4,00)$. Murashige and Skoog (MS) medium was the best medium and concentrations for $C$. bicolor growth at the subculture stage.

Keywords: Cymbidium bicolor, subculture, growth, variation of media

\section{PENDAHULUAN}

Indonesia merupakan salah satu negara yang memiliki keanekaragaman hayati yang sangat beragam. Salah satu keanekaragaman hayati yang ada di Indonesia adalah anggrek. Jumlah anggrek di Indonesia sekitar 5000 spesies dari 25.000 spesies yang ada di dunia (Kasutjianingati \& Irawan, 2013). Salah satu anggrek yang ada di Indonesia adalah Cymbidium bicolor. Anggrek $C$. bicolor merupakan salah satu anggrek spesies yang banyak ditemukan di alam seperti di hutan Sumatera dan Jawa, tetapi belum banyak dijadikan tanaman hias seperti kebanyakan anggrek yang lain (Fitri \& Santoso, 2013). Anggrek $C$. bicolor dapat menjadi tanaman hias karena anggrek ini memiliki bunga yang indah dan tahan lama sehingga memiliki daya tarik untuk dikoleksi dan dapat diperjualbelikan. Anggrek C. bicolor mulai dieksploitasi dari alam karena memiliki nilai ekonomis sehingga perlu dibudidayakan. Salah satu metode budidaya yang digunakan untuk perbanyakan anggrek adalah kultur jaringan tumbuhan.

Kultur jaringan tumbuhan merupakan teknik budidaya bagian tanaman yang dilakukan pada suatu lingkungan yang aseptik misalnya pada medium yang steril di dalam botol (Ikenganyia et al. 2017). Salah satu tahapan yang penting dalam kultur jaringan tumbuhan adalah subkultur. Subkultur adalah proses pemindahan planlet dari satu media ke media yang baru setelah periode tertentu. Tujuan dari subkultur adalah menggantikan media yang lama ke media yang baru sehingga nutrisi tanaman tetap tercukupi (Rodinah dkk., 2018). Salah satu faktor yang mempengaruhi pertumbuhan planlet adalah media. Media dalam kultur jaringan mengandung beberapa komponen yang bermanfaat untuk pertumbuhan tanaman seperti makronutrien, mikronutrien, asam amino, vitamin, dan myoinositol (Jaime \& Silva, 2015).

Media yang digunakan dalam kultur jaringan antara lain media MS (Murashige and Skoog), VW (Vacin and Went), dan media NP (New Phalaenopsis). Media MS merupakan salah satu media yang sering digunakan dalam kultur jaringan tumbuhan karena media ini menghasilkan respon yang baik pada banyak tanaman, seperti pada anggrek Cymbidium aloifolium (Pradhan et al., 2013), sagu (Metroxylon sago) (Nurhidayah dkk., 2017), dan kentang (Solanum tuberosum) (Setiawati dkk., 2018). Keunggulan media MS adalah memiliki kandungan nitrogen yang tinggi yang memiliki banyak manfaat untuk pertumbuhan tanaman (Leghari et al. 2016). Beberapa penelitian menggunakan medium MS, VW, dan NP yang mampu meningkatkan pertumbuhan dalam kultur jaringan tumbuhan yaitu penelitian dari Akter et al. (2007) yang menunjukkan bahwa media MS mampu meningkatkan pertumbuhan Protocorm like body (Plb) pada eksplan anggrek Dendrobium. Media VW meningkatkan perkecambahan sampai $100 \%$ dan pembentukan tunas sampai $84 \%$ pada Dendrobium lasianthera (Utami et al., 2017). Penelitian Krisdianto dkk. (2020) juga menunjukan bahwa media NP menghasilkan pertumbuhan yang optimal pada pertumbuhan tunas Phalaenopsis amabilis dari eksplan berupa plb.

Pertumbuhan anggrek $C$. bicolor pada tahap subkultur dengan variasi jenis media perlu dilakukan untuk menghasilkan anggrek yang unggul, oleh karena itu tujuan penelitian ini untuk menganalisis pertumbuhan planlet $C$. bicolor pada tahap subkultur dengan variasi media. 


\section{MATERI DAN METODE}

\section{Tempat dan waktu penelitian}

Penelitian ini dilaksanakan di Laboratorium Kultur Jaringan Biologi Struktur dan Fungsi Tumbuhan Departemen Biologi, Fakultas Sains dan Matematika, Universitas Diponegoro, Semarang. Penelitian dilaksanakan di bulan Januari - Maret 2020.

\section{Bahan}

Sumber eksplan berasal dari planlet $C$. bicolor umur \pm 1 tahun. Bahan lain yang digunakan adalah alkohol 70\%, akuades, media dasar kultur MS, VW, dan NP siap pakai, $\mathrm{HCl}, \mathrm{NaOH}$, sukrosa, dan agar.

\section{Pembuatan Media}

Media MS sebesar 1,67 g/L, VW sebesar 4,43 $\mathrm{g} / \mathrm{L}, \mathrm{NP}$ sebesar 25,35 g/L yang sudah siap pakai ditimbang, selanjutnya sukrosa sebesar $30 \mathrm{~g} / \mathrm{L}$, dan agar sebesar $8 \mathrm{~g} / \mathrm{L}$ ditimbang di neraca analitik. Selanjutnya akuades dengan volume 500 $\mathrm{mL}$ dimasukkan ke dalam gelas beker dan dipanaskan. Media MS atau VW dimasukkan ke dalam gelas beker dan dihomogenkan. Sukrosa 30 g/L kemudian dimasukkan ke gelas beker dan dihomogenkan. Kemudian dilakukan pengukuran $\mathrm{pH}$ sebesar 5,8 - 6 dengan kertas indikator $\mathrm{pH}$ meter. Jika $\mathrm{pH}$ terlalu asam ditambahkan $\mathrm{NaOH}$ dan jika $\mathrm{pH}$ terlalu basa ditambahkan $\mathrm{HCl}$ sampai $\mathrm{pH}$ sesuai 5,8 - 6. Agar pemadat $8 \mathrm{~g} / \mathrm{L}$ dimasukkan ke dalam gelas beker dan ditambahkan $500 \mathrm{~mL}$ akuades kemudian dihomogenkan hingga mendidih. Medium dituang ke botol kultur kemudian ditutup dengan aluminium foil dan plastic wrap. Media NP berbeda dari media MS dan VW karena dalam media NP sudah mengandung sukrosa dan agar sehingga langsung dihomogenkan. Selanjutnya media di sterilisasi dengan autoklaf pada suhu $121^{\circ} \mathrm{C}$ selama 15 menit.

\section{Penanaman Eksplan}

Penanaman dilakukan dengan cara mengambil masing-masing planlet dengan pinset steril kemudian diletakkan di cawan petri untuk dibersihkan dari media yang menempel pada planlet. Setelah dibersihkan, eksplan ditanam pada media perlakuan yaitu media MS, VW, dan NP. Masing-masing berisi 3 planlet dengan ukuran seragam dengan 5 kali ulangan. Botol ditutup dengan aluminium foil dan dilapisi plastic wrap. Botol diberi label sesuai perlakuan dan tanggal penanaman. Botol kultur diinkubasi di tempat terang dengan cahaya lampu $1000-4000$ lux dan suhu $25^{\circ} \mathrm{C}$

\section{Pengamatan}

Parameter penelitian yang diamati antara lain kemunculan daun baru, jumlah daun, panjang daun, lebar daun, jumlah akar, panjang akar, dan jumlah tunas. Parameter penelitian diamati setiap minggu sekali dengan pengamatan langsung selama 2 bulan penanaman. Tanaman diamati, didokumentasikan dan dicatat parameter yang diamati. Pengukuran panjang daun, lebar daun dan panjang akar dilakukan menggunakan aplikasi Image Raster 3.

\section{Analisis data}

Penelitian ini menggunakan Rancangan Acak Lengkap (RAL) dengan faktor tunggal yaitu Jenis Media. Setiap perlakuan diulang sebanyak 15 kali. Data dianalisis dengan Analysis of Varians (ANOVA) pada taraf kepercayaan 95\%. Jika terdapat pengaruh yang signifikan maka dilakukan uji lanjut dengan menggunakan uji DMRT (Duncan's Multiple Range Test).

\section{HASIL}

Hasil penelitian pertumbuhan anggrek Cymbidium bicolor Lindl. pada tahap subkultur dengan variasi media meliputi beberapa parameter yang diamati yaitu kemunculan daun baru, jumlah daun, panjang daun, lebar daun, jumlah akar, panjang akar, dan panjang tunas.

\section{Daun}

Hasil ANOVA menunjukkan jenis media berpengaruh nyata terhadap kemunculan daun baru, jumlah daun, panjang daun, dan lebar daun C. bicolor. Kemunculan daun paling cepat pada 
media MS yaitu pada hari ke 11 (Gambar 1). Jumlah daun terbanyak terdapat pada planlet yang disubkultur ke media MS yaitu sebanyak 4,92 helai (Gambar 2). Planlet yang disubkultur ke media MS kemunculan daun barunya paling cepat sehingga planlet yang disubkultur ke media MS tersebut mempunyai daun paling banyak.

Daun terpanjang $(1,56 \mathrm{~cm})$ terdapat pada planlet media MS (Gambar 3). Daun terlebar $(0,33 \mathrm{~cm})$ terdapat pada planlet media MS (Gambar 4). Planlet pada media MS mempunyai daun paling panjang dan paling lebar.

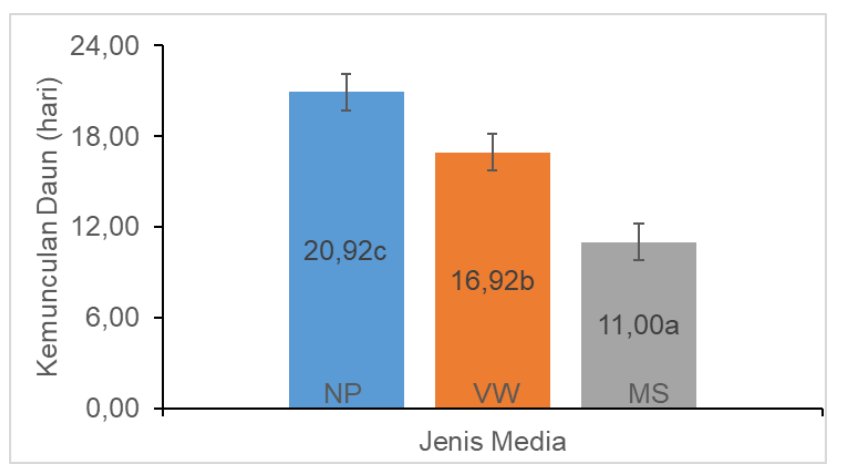

Gambar 1. Rata-rata kemunculan daun (hari) planlet $C$. bicolor pada perlakuan variasi media (NP, VW dan MS)

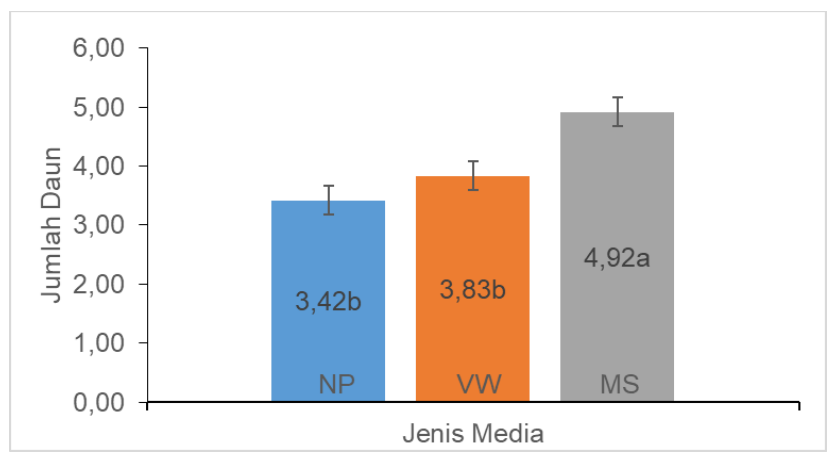

Gambar 2. Rata-rata jumlah daun planlet $C$. bicolor pada perlakuan variasi media (NP, VW dan MS)

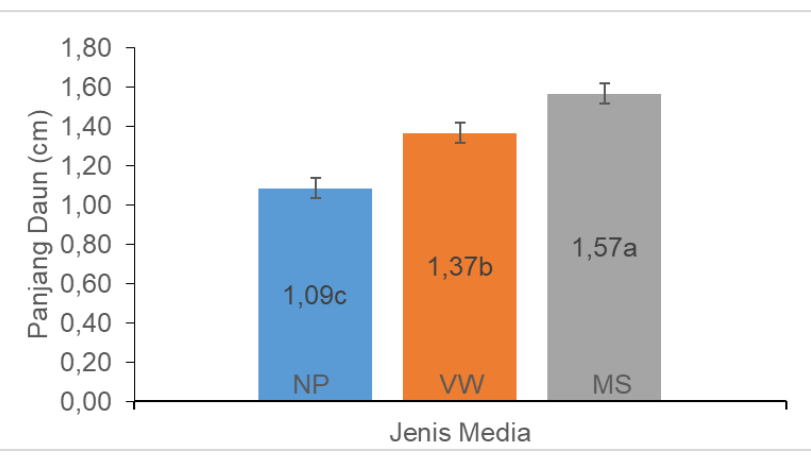

Gambar 3. Rata-rata panjang daun $(\mathrm{cm})$ planlet $C$. bicolor pada perlakuan variasi media (NP, VW dan MS)

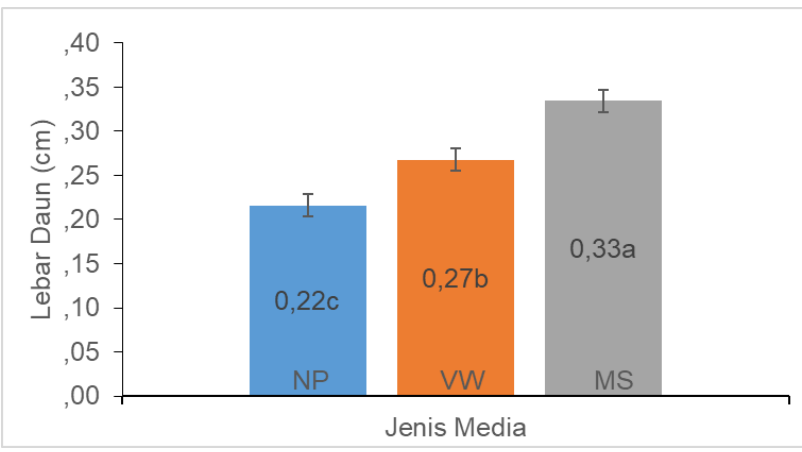

Gambar 4. Rata-rata lebar daun (cm) planlet $C$. bicolor pada perlakuan variasi media (NP, VW dan MS)

\section{Akar}

Hasil ANOVA menunjukkan hasil jenis media berpengaruh nyata terhadap jumlah akar dan panjang akar $C$. bicolor. Jumlah akar paling banyak $(2,67)$ terdapat pada media MS (Gambar 5). Akar terpanjang $(2,73 \mathrm{~cm})$ terdapat pada media MS (Gambar 6). Jumlah akar dan panjang akar terbaik planlet $C$. bicolor terdapat pada media MS.

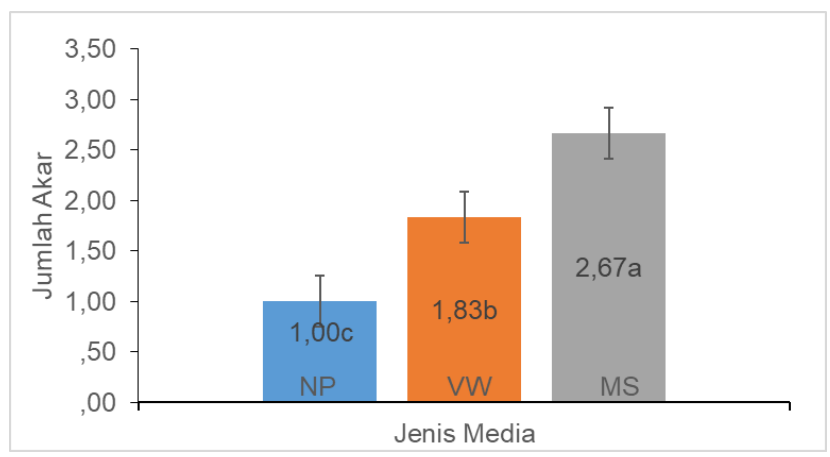

Gambar 5. Rata-rata jumlah akar planlet $C$. bicolor pada perlakuan variasi media (NP, VW dan MS)

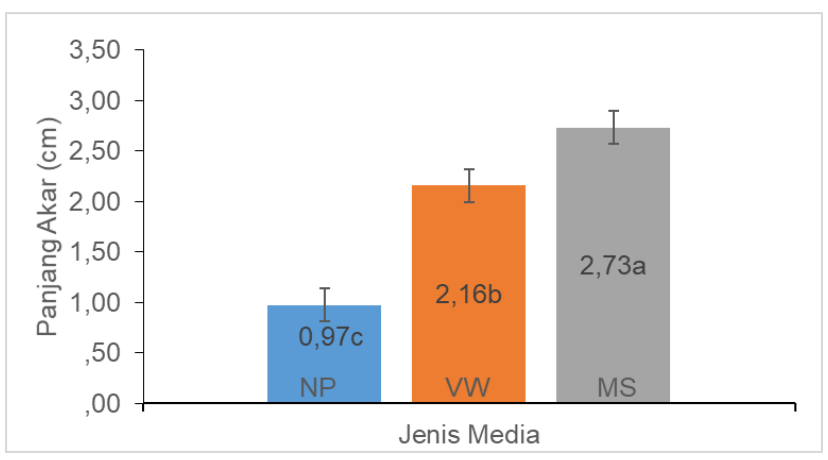

Gambar 6. Rata-rata panjang akar $(\mathrm{cm})$ planlet $C$. bicolor pada perlakuan variasi media (NP, VW dan MS) 


\section{Tunas}

Hasil ANOVA menunjukkan hasil jenis media berpengaruh nyata terhadap jumlah tunas $C$. bicolor. Jumlah tunas paling banyak terdapat pada media MS dengan jumlah 4,00. Planlet pada media MS memiliki jumlah tunas paling banyak (Gambar 7 dan 8).

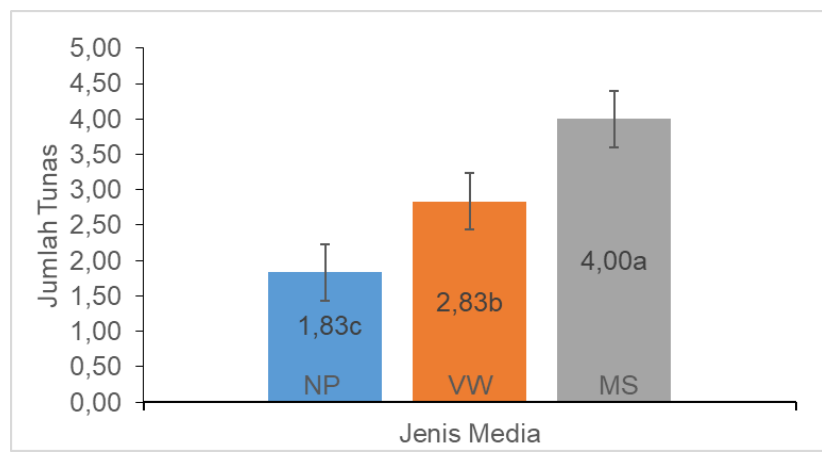

Gambar 7. Rata-rata jumlah tunas planlet $C$. bicolor pada perlakuan variasi media (NP, VW dan MS)

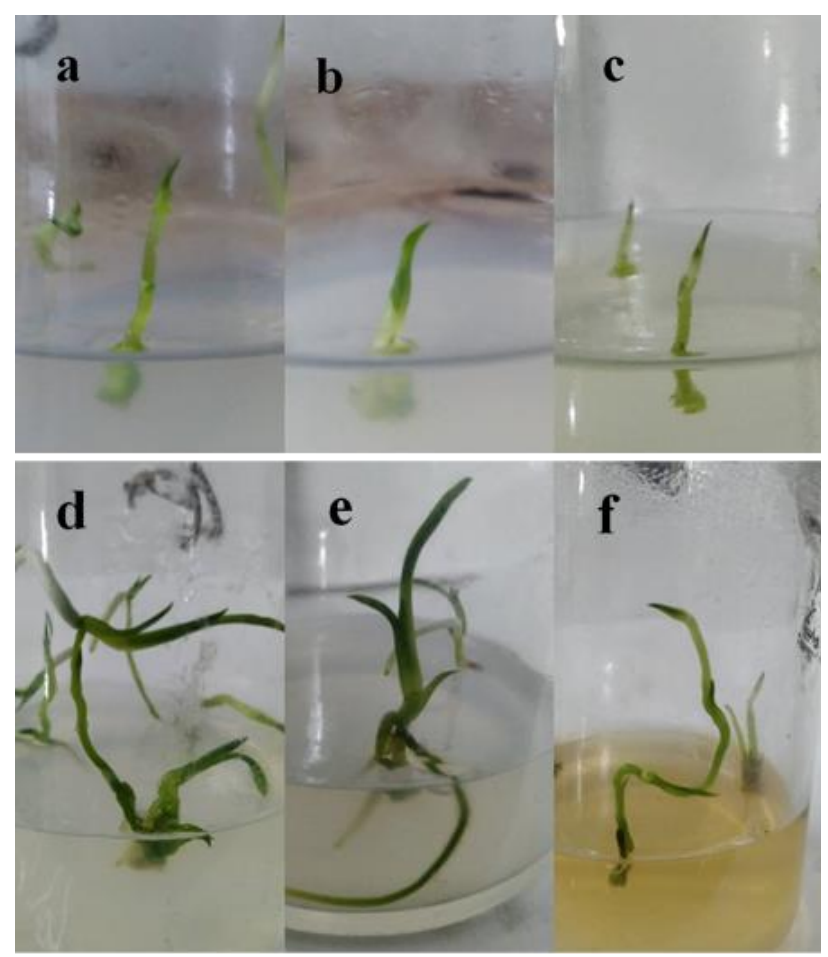

Gambar 8. Eksplan Cymbidium bicolor minggu ke-0 (a. Media MS, b. Media VW, c. Media NP) dan planlet $C$. bicolor pada minggu ke-8 (d. Media MS, e. Media VW, f. Media NP)

\section{PEMBAHASAN}

Hasil penelitian menunjukkan bahwa jenis media berpengaruh nyata terhadap semua parameter dengan jenis media terbaik adalah media MS. Hal ini disebabkan karena media MS merupakan media dengan kandungan makronutrien dan mikronutrien paling lengkap dibandingkan dengan media VW dan NP. Hal ini sesuai dengan Uche et al. (2016), bahwa media MS merupakan media dengan kandungan makronutrien dan mikronutrien yang lengkap. Makronutrien yang terkandung dalam media MS adalah nitrogen $(\mathrm{N})$, fosfor $(\mathrm{P})$, kalium $(\mathrm{K})$, kalsium $(\mathrm{Ca})$, magnesium $(\mathrm{Mg})$, dan sulfur $(\mathrm{S})$. Selain itu, media MS juga mengandung mikronutrien dan kandungan tambahan seperti vitamin dan asam amino yang tidak ada pada media VW. Hal ini sesuai dengan Pradhan et al. (2013) bahwa media MS mengandung vitamin seperti thiamin dan asam amino seperti glisin yang penting untuk pertumbuhan plantlet.

Media MS memiliki kadar nitrogen $(\mathrm{N})$ yang tinggi. Nitrogen yang terkandung di dalam media MS memiliki bentuk nitrat $\left(\mathrm{NO}^{3-}\right)$ dan ammonium $\left(\mathrm{NH}^{4+}\right)$. Ion nitrat dan ammonium mampu membentuk senyawa yang lebih kompleks. Ion ammonium yang diserap atau hasil reduksi nitrat akan di metabolisir menjadi asam amino glutamin, asam glutamat, dan arginin. Asam amino glutamat berperan dalam membentuk konjugat auksin atau auksin yang tidak aktif. Hormon auksin berperan untuk pemanjangan sel pada daun dan akar. Mekanisme kerja auksin adalah dengan merangsang pompa ion $\mathrm{H}^{+} \mathrm{ke}$ dinding sel. Ion $\mathrm{H}^{+}$kemudian menurunkan $\mathrm{pH}$ dinding sel dan mengaktifkan enzim ekspansin dalam dinding sel yang memutus beberapa ikatan silang hidrogen rantai molekul selulosa penyusun dinding sel sehingga meningkatkan plastisitas dinding sel. Hal tersebut menyebabkan air menjadi masuk secara osmosis ke dalam sel. Masuknya air ke dalam sel dan didukung dengan dinding sel yang plastis menyebabkan terjadinya pemanjangan sel. Hal ini menyebabkan terjadinya pemanjangan pada panjang dan lebar daun serta panjang akar. Panjang dan lebar daun serta panjang akar dipengaruhi oleh mekanisme kerja auksin tersebut sehingga menyebabkan pertumbuhan meningkat.

Unsur lain yang berperan untuk pertumbuhan anggrek $C$. bicolor adalah magnesium $(\mathrm{Mg})$. 
Magnesium merupakan hara makro yang dibutuhkan untuk proses fotosintesis pada daun. Unsur ini mengaktifkan enzim ribulose - 1,5 bisphosphate (RuBP) yang berperan dalam mengikat karbon dalam proses fotosintesis. Menurut Yang et al. (2012) semakin banyak enzim rubisco mengikat karbon, mampu meningkatkan laju fotosintesis dan pembentukan protein. Laju fotosintesis yang meningkat menyebabkan fotosintat menjadi meningkat juga. Fotosintat yang merupakan hasil fotosintesis digunakan untuk pertumbuhan planlet (Pertamawati, 2010). Magnesium merupakan satu-satunya unsur logam yang berperan dalam menyusun klorofil. Magnesium berperan langsung dalam menentukan struktur klorofil dengan terikat menjadi atom pusat bersama nitrogen dan hidrokarbon membentuk cincin porfirin (Wirawan et al. 2016).

Media VW dan NP merupakan media yang memiliki hasil kurang optimal pada penelitian kali ini. Hal ini karena media VW memiliki kandungan makronutrien dan mikronutrien yang jumlah dan jenisnya lebih sedikit dibandingkan dengan media MS sehingga menyebabkan hara yang diserap oleh tanaman menjadi lebih sedikit. Selain itu media VW tidak memiliki kandungan asam amino dan vitamin (Rahmah et al. 2018). Salah satu senyawa VW adalah $\mathrm{KNO}^{3}$ memiliki jumlah $0.525 \mathrm{mg} / \mathrm{L}$, lebih sedikit dibandingkan dengan media MS yang memiliki jumlah $1.900 \mathrm{mg} / \mathrm{L}$. Media NP juga memiliki hasil yang kurang optimal karena media NP merupakan media yang digunakan khusus untuk pertumbuhan anggrek Phalaenopsis sehingga diduga kurang cocok digunakan pada anggrek $C$. bicolor (Merthaningsih \& Yuswanti, 2018). Selain itu, kandungan N pada media NP 5 kali lebih rendah dari media MS yaitu $160,7 \mathrm{mg} / \mathrm{L}$ sedangkan media MS memiliki kandungan $\mathrm{N}$ yaitu $840,8 \mathrm{mg} / \mathrm{L}$.

\section{SIMPULAN}

Jenis media berpengaruh nyata terhadap pertumbuhan planlet $C$. bicolor. Media MS merupakan media terbaik dalam mempengaruhi pertumbuhan planlet $C$. bicolor pada tahap subkultur karena komposisi mineral media MS lebih lengkap dibanding media VW dan NP.

\section{UCAPAN TERIMA KASIH}

Penulis mengucapkan terimakasih kepada Laboratorium Biologi Struktur dan Fungsi Tumbuhan Departemen Biologi, Fakultas Sains dan Matematika, Universitas Diponegoro, Semarang.

\section{KEPUSTAKAAN}

Akter S, Nasiruddin K, Khaldun A. 2007. Organogenesis of Dendrobium Orchid Using Traditional Media and Organic Extracts. Journal of Agriculture \& Rural Development 5(1\&2): 30-35.

Fitri ASS, Santoso AM. 2013. Ragam Orchidaceae Epifit di Kawasan Ubalan Kediri dan Prospeknya Sebagai Modal Bioekonomi Lokal. Proceeding Biology Education Conference 11(1): 365-370

Ikenganyia E, Anikwe M, Omeje T, Adinde J. 2017. Plant Tissue Culture Regeneration and Aseptic Techniques. Asian Journal of Biotechnology and Bioresource Technology 1(3): 1-6.

Jaime A, Silva T da. 2015. Ammonium to Nitrate Ratio Affects Protocorm Like Bodies PLB Formation In vitro of Hybrid Cymbidium. Journal of Ornamental Plants (Journal of Ornamental and Horticultural Plants) 3(3): 155-160

Kasutjianingati, Irawan R. 2013. Media Alternatif Perbanyakan In Vitro Anggrek Bulan (Phalaenopsis amabilis). Jurnal Agroteknos 3(3): 184-189

Krisdianto A, Saptiningsih E, Nurchayati Y, Setiari N. 2020. Pertumbuhan Plantlet Anggrek Phalaenopsis amabilis (L.) Blume Pada Tahap Subkultur Dengan Perlakuan Jenis Media Dan Konsentrasi Pepton Berbeda. Jurnal Metamorfosa: Journal of Biological Sciences 7(2): 40-47.

Leghari SJ, Wahocho NA, Laghari GM, HafeezLaghari A, MustafaBhabhan G, HussainTalpur K, Lashari AA. 2016. Role of nitrogen for plant growth and development: 
a review. Advances in Environmental Biology 10(9): 209-219

Merthaningsih NIP, Yuswanti H. 2018. Induksi Kalus pada Kultur Pollen Phalaenopsis dengan Menggunakan 2,4 Diklorofenoksiasetat. Agrotrop 8(1): 47-55

Nurhidayah T, Mardhiansyah M, Mulyani D. 2017. Pengaruh Sitokinin (Kinetin) dan Auksin (2,4 D) dalam Media Induksi Murashige dan Skoog terhadap Perkembangan Eksplan Meristem Apikal Tunas Anakan Tanaman Sagu (Metroxylon sagu Rottb.). Jurnal Agrotek Tropika 6(1): 23-28

Pertamawati. 2010. Pertumbuhan Tanaman Kentang (Solanum tuberosum L.) Dalam Lingkungan Fotoautotrof secara In vitro. Jurnal Sains dan Teknologi Indonesia 12(1): 31-37

Pradhan S, Regmi T, Parmar G, Pant B. 2013. Effect of Different Media on in vitro Seed Germination and Seedling Development of Cymbidium aloifolium (L.) Sw. Nepal Journal of Science and Technology 14(1): 51-56.

Rahmah S, Rahayu T, Hayati A. 2018. Kajian penambahan bahan organik pada media tanam VW pada organogenesis anggrek Dendrobium secara in vitro. Jurnal Sains Alami 1(1): 93-103

Rodinah R, Hardarani N, Ariani HD. 2018. Modifikasi Media Dan Periode Subkultur Pada Kultur Jaringan Pisang Talas (Musa paradisiaca VAR. SAPIENTUM L.). Jurnal Hexagro 2(2): 1-6.

Setiawati T, Zahra A, Budiono R, Nurzaman M. 2018. Perbanyakan In Vitro Tanaman Kentang (Solanum tuberosum [L.] cv. Granola) dengan Penambahan METATOPOLIN pada Media Modifikasi MS (Murashige \& Skoog). Jurnal Metamorfosa: Journal of Biological Sciences 5(1): 44-50

Uche OC, Ejiofor AP, Eziuche OC. 2016. (Comparative Growth Rates of Treculia africana Decne: Embryo in Varied Strengths of Murashige and Skoog Basal Medium). International Journal of Agricultural and Biosystems Engineering 10(9): 564-567

Utami ESW, Hariyanto S, Manuhara YSW. 2017. In vitro propagation of the endangered medicinal orchid, Dendrobium lasianthera J.J.Sm through mature seed culture. Asian Pacific Journal of Tropical Biomedicine 7(5): 406-410.

Wirawan BDS, Putra ETS, Yudono P. 2016. Pengaruh Pemberian Magnesium, Boron dan Silikon terhadap Aktivitas Fisiologis, Kekuatan Struktural Jaringan Buah dan Hasil Pisang (Musa acuminata) "Raja Bulu." Vegetalika 5(4): 1-14.

Yang GH, Yang LT, Jiang HX, Li Y, Wang P, Chen LS. 2012. Physiological impacts of magnesium-deficiency in Citrus seedlings: Photosynthesis, antioxidant system and carbohydrates. Trees - Structure and Function 26(4): 1237-1250. 